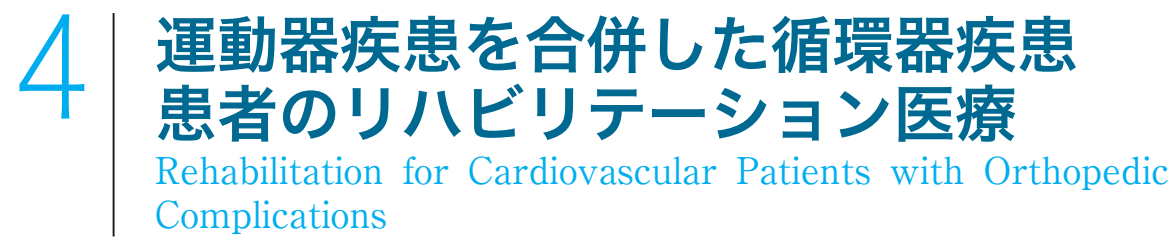

牧田 茂*

Shigeru Makita

Key words：ロコモティブシンドローム/心臟リハビリテーション／リスク管理

心疾患, 高血圧, 糖尿病といった内科疾患に対する有酸素運動の効果はすでに広く知られて いるが, 高齢化に伴い併存疾患をもつ患者が増加している。特に, 変形性関節症や変形性脊 椎症などの整形外科的疾患をもつ患者への運動指導が問題となってくる.

膝・腰などの運動器の痛みとそれに伴う運動や生活機能の低下を幅広く含む新しい概念とし てロコモティブシンドローム (ロコモ) が, 2009 年日本整形外科学会から提唱された。

コモを保有することで，内科疾患に欠かすことのできない歩行を中心とする有酸素運動が十 分に実践できないことがあり、ロコモ対策は重要である。ロコモを有する内科疾患患者が有 酸素運動を行う場合は, 循環器系疾患を念頭に置いた評価とリスク管理が必要である.

\section{心臓リハビリテーションの 概要}

心臟リハビリテーションは, かつては離床とデコ ンディショニング予防が主たる目的であったが，急 性期における再灌流療法や coronary care unit （CCU）の普及, 冠動脈バイパス術などの術式の進 歩により早期離床・早期退院が可能となった。 そ のため危険因子是正による二次予防（再発予防） のための心蔵リハビリテーションへと目的が変わっ てきている。「心臓リハビリテーションとは，心血 管疾患患者の身体的 - 心理的 - 社会的 - 職業的状 態を改善し, 基礎にある動脈硬化や心不全の病態

* 埼玉医科大学国際医療センター 心臟リハビリテーション科

（テ350-1298 埼玉県日高市山根 1397-1）

E-mail : mshigeru-stm@umin.ac.jp DOI : $10.2490 /$ jjrmc.55.829
の進行を抑制あるいは軽減し, 再発・再入院・死亡 を減少させ, 快適で活動的な生活を実現すること をめざして, 個々の患者の『医学的評価・運動処方 に基づく運動療法・冠危険因子是正・患者教育お よびカウンセリング・最適薬物治療』を多職種チー ムが協調して実践する長期にわたる多面的・包括 的プログラムをさす」と定義されている1).このよ うに考えると, 心臓リハビリテーションは単に運動 療法のみを行っていれば事足りるものではなく, 食 事療法や禁煙指導を含めた包括的 (comprehensive）リハビリテーションをめざすべきである.こ の目的を達成するためには, 医療専門職がチーム で対処していかねばならない（図 1)。さらに，患 者のセルフコントロール支援のためには長期的な 関与が求められている. したがって, 急性期や回 復期のみならず, 維持期を含めた心臟リハビリテー ションシステムの構築が必要である. 


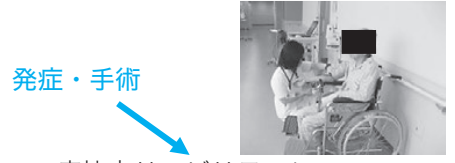

病棟内リハビリテーション

(早期離床)

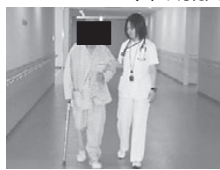

心臓リハビリテーション カンファレンス

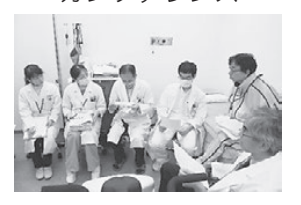

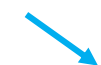

運動負荷試験

と運動・生活指導

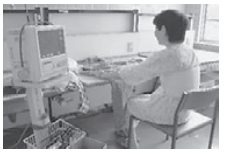

臨床検査技師：運動負荷試験や 各種生理機能検査

看護師 ：患者指導・教育

管理栄養士 : 栄養指導
$\mathrm{PT}$ : 早期離床と基本動作 - 歩行訓練

OT : ADL（特に，家事動作）と職場復帰

に向けての指導・訓練
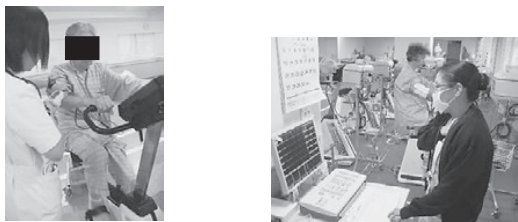

リハビリテーションセンターでの

エルゴメータ訓練（運動耐容能向上）

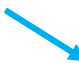

退院後

外来通院型

心臓リハビリテーション

定期的に運動負荷試験と 運動指導を実施

図 1 心臓リハビリテーションの流れ

\section{ロコモティブシンドロームと 心臓リハビリテーション}

ロコモテイブシンドローム（ロコモ）とは,「運動 器の障害」により「要介護になる」リスクの高い状 態として，日本整形外科学会が 2007 年に新たに提 唱した症候群である。ロコモの代表的疾患として， 骨粗鬆症，変形性関節症，脊椎管狭窄が挙げられ ており，これらの疾患では疼痛，関節可動域制限， 筋力低下, バランス能力低下をきたすので, 移動機 能の低下すなわち歩行障害を中心とする ADL 制 限から社会活動制限や転倒が引き起こされ，結果 的に要介護となることが懸念される。そそのため,こ のような状態を早期に発見して（ロコチェック）, 予防する（ロコトレ）ことを推奨している．要する に, 運動器の面からの移動動作，起居動作の障害 いわゆる ADL 障害に着目して, 積極的に予防策を 講ずることで転倒や要介護状態に陥ることを防い でいくという考え方である.
一方，心臓リハビリテーションとは，動脈硬化症 の代表的な表現型である虚血性心疾患の悪化予防 や再発予防のために患者教育・指導を通じて疾病 管理を行い，QOL 向上や予後改善を目標とするも のである.メタボリックシンドローム（メタボ）も 同様の考え方であり，内臟脂肪過剩蓄積を基盤に して，過栄養と運動不足を背景にして増加する動 脈硬化性心血管病の予防のために確立された症候 群である。

このように，ロコモとメタボは考え方やアプロー チが異なるが，両者には重要な共通点がある。そ れは，今後わが国では心疾患を単独でもつ患者よ り併存疾患をもつ患者が増え, 特に運動器障害を もつ高齢心不全患者が急増してくることが予想さ れている。 また，反対にロコモ保有患者において も，高齢化と同時に心疾患をもつ患者も当然増え てくる.したがって，このような患者を目の前にし て運動器疾患と循環器疾患の双方に配慮した対処 が必要となる。 
心臓リハビリテーションの立場から考えると, $\mathrm{ADL}$ (特に, 歩行能力) に問題がある, または将来 問題となりそうな患者を対象にして, スクワットや 開眼片足立ちの指導を注意して行えば循環器系に 大きな負荷とはならずに歩行能力が改善すること が期待される．神経症状や痛みがある際は整形外 科専門医に判断を仰ぐことも必要となるだろう。 回復期から維持期にかけてのロコチェックとロコト レは, 有酸素トレーニングを有効に行うための（す なわち動脈硬化予防の運動療法を効果的に行うた めの）コンディショニングトレーニングと考えられ る.ただし，スクワットや開眼片足立ち以外のロコ トレは, 種目によっては循環器系に大きな負荷が 加わる可能性があるため, 個別に運動負荷試験に よる事前のチェックと適切な運動処方が必要であ ろう.

ロコモを有する心疾患患者への運動指導に関し ては, 日本心臓リハビリテーション学会認定の心 臓リハビリテーション指導士を積極的に活用し, こ れらの指導士にロコモの観点からの講習・実習を 追加して行えば, 心疾患患者に対して安全で効果 的な個別トレーニングを普及させることができると 考える1).

\section{ロコモティブシンドロームを 合併した心疾患患者の 運動療法における注意点}

ロコモを合併した患者における心臓リハビリ テーションにおいての注意点を以下に挙げる.

\section{1. 運動の可否判断}

運動器疾患が急性期の場合は運動療法を控える 必要がある. 運動の可否を整形外科専門医や理学 療法士（PT）などに確認して指示を仰ぐ。診察の 際には既往を有する関節の痛みや腫れなどをみて, 炎症の有無を観察することが重要である．筋力測

\section{表 1 運動療法における禁忌}

1. 非代償性心不全

2. 不安定狭心症

3. 重症不整脈（特に，運動誘発性）

4. 重度の弁膜症（特に, 大動脈弁狭窄症）

5. 左主幹部有意狭窄 (3 枝病変も要注意)

6. 心筋炎急性期

7. 閉塞性肥大型心筋症

8. 大動脈解離, 大動脈瘤（急性期）

9. その他 急性疾患, コントロールされていない疾患, 運動が禁止されている骨関節疾患, 重症疾患

注 : デコンディショニング予防, ADL アップのためリスク に十分注意しながら進める場合もある $\rightarrow$ 高齢合併症患 者で手術非適応例など

定や関節可動域測定を実施して歩行制限の評価を 行って運動指導につなげていく. また, 循環器疾 患の運動療法に際しては, 禁忌疾患を事前に鑑別 しておくことも重要である（表 1）。

\section{2. 運動療法実施}

運動中のほか, 翌日以後にも痛みの出現がない かの確認をし, 悪化の恐れがある場合にはその運 動を中断して運動内容を再検討し, 関節に負担の かからない運動方法を検討する. 自転車エルゴ メータはトレッドミルと比較して関節負担が少ない ため推奨される. ローイングエルゴメータや上肢 エルゴメータを用いたり, 水中運動を取り入れるこ ともよい. 心臓リハビリテーションは主として歩行 やエルゴメータを中心とした有酸素運動を行うの が通常であるが，ロコモを有する患者では通常の 心臓リハビリテーション対象患者のように漸増負 荷による心肺運動負荷試験を行うことが難しく, 個別リハビリテーションプログラムを適用する場合 も多い.

\section{3. 循環器系へのリスク管理}

既往として心臓疾患や高血圧, 糖尿病などの把 握をしておく，運動による痛みで血圧が上昇する と，心臓への過負荷につながるため注意を要する. 


\section{表 2 運動療法中の循環器疾患リスク管理}

·胸部症状 (胸痛·圧迫感 ·不快感 · 動悸), 呼吸困難な どの自覚（他覚）症状がないこと

- 心拍数が 120 拍/分以上もしくは安静時より 40 拍/分以 上上昇しないこと

・危険な不整脈が出現しないこと（症例別に危険度は判 断)

· ST低下・T波の陰転化・ST 上昇がみられないこと

·著しい血圧上昇がないこと（発症より 2 週間以内は 20 $\mathrm{mmHg}$ 以内, それ以降は $30 \mathrm{mmHg}$ 以内を上限とす る). また, $20 \mathrm{mmHg}$ 以上の低下がないこと

弱めの負荷から開始し，過度な心負荷を避けるた め, 動作はゆっくり行わせ頻回の休みを入れる。 ま た，連続した長時間の動作は控える，心拍数，血 圧, 自覚的運動強度 (ボルグ指数), 自覚症状 (痛 み)，酸素飽和度などのチェックを行うが，等尺性 運動は血圧が上昇しやすいとされ，レジスタンスト レーニングの際には, 呼吸法を指導してバルサル バ負荷を避けるべきである。 また，心電図モニター で不整脈の有無や運動時の心拍数上昇や虚血性変 化に注意する ${ }^{2)}$. 心電図モニターのみで判断がつ かない場合は, 12 誘導心電図測定を行う（表 2).

\section{4. 体重コントロール}

体重を減らして関節負担を軽減することは重要
である. 食事療法でのカロリー制限を併用して行 う.

\section{まとめ}

(1)日本は高齢化とともに併存疾患を抱える心疾患 患者, 特に心不全患者の増加が予想され, ロコ モの観点からのアプローチが必要となる.

(2) ADLの低下した心疾患患者にはロコトレが必 要である. 特に, レジスタンストレーニングは必 要と思われる. また, ロコトレによって移動能力 が向上した患者には, 積極的な有酸素トレーニ ングが必要である.

(3)心疾患患者にロコトレを実施する際には, 循環 器系への負荷に十分配慮した運動処方と運動指 導が必要である.

\section{文献}

1）日本心臟リハビリテーション学会ホームページ. Available from URL : http://square.umin.ac.jp/we b/about/statement

2) 循環器病の診断と治療に関するガイドライン 2011 年 度合同研究班: 心血管疾患に扔けるリハビリテーショ ンに関するガイドライン (2012 年改訂版)。Available from URL : http://www.j-circ.or.jp/guideline/p df/JCS2012_nohara_h.pdf 